\title{
Protected Homocysteine Peptides as Precursors of Labelled Methionine Peptides. Application in Preparation of
} Methionine-Enkephalin

\author{
KJELL NÅGREN, ${ }^{\mathrm{a}, \mathrm{b}}$ BENGT LÅNGSTRÖM ${ }^{\mathrm{a}}$ and ULF RAGNARSSON ${ }^{\mathrm{b}}$
}

a Institute of Chemistry, University of Uppsala, Box 531, S-751 21 Uppsala, Sweden and

${ }^{b}$ Institute of Biochemistry, Biomedical Center, University of Uppsala, Box 576, S-751 23 Uppsala, Sweden

A synthetic scheme from $\boldsymbol{N}$-benzyloxycarbonyl $\boldsymbol{S}$-benzyl homocysteine peptide benzyl ester, assembled using well-established procedures in solution and purified, to the corresponding free methionine peptide, has been explored preparatively. Deprotection by sodium in liquid ammonia followed by alkylation on sulfur with methyl iodide gave, after purification by semipreparative HPLC, in the case of methionine-enkephalin a pure product in high yield. No evidence from side-reactions on tyrosine could be detected by HPLC. The scheme was primarily designed to be adaptable to the preparation of ${ }^{11} \mathrm{C}$-labelled methionine-enkephalin and, in particular, to exploit ${ }^{11} \mathrm{C}$-methyl iodide, now in routine production in our laboratory, in peptide synthesis, thus providing access to ${ }^{11} \mathrm{C}$-labelled enkephalins with high specific radioactivity for in vivo experiments. Applying ${ }^{2} \mathrm{H}-,{ }^{3} \mathrm{H}$-, ${ }^{13} \mathrm{C}$ - or ${ }^{14} \mathrm{C}$-methyl iodide instead, however, this approach should be equally useful for the preparation of the corresponding peptides. Provided overalkylation by methyl iodide and fatal splitting of peptide bonds by the sodium/ammonia reagent can be avoided, the scheme should be applicable also to the synthesis of other methionine-containing peptides.

Because of the high specific radioactivity obtained, the low radiation dose distributed and the advantage of external detection, ${ }^{11} \mathrm{C}$-labelling of various biologically active compounds offers unique possibilities of studying such molecules in vivo. The developments in accelerator technology as well as the recent availability of commercial, versatile detectors for annihilation photons, have created a demand among biologists for ${ }^{11} \mathrm{C}$-labelled substances in general to be used in positron emission tomography (PET). Owing to the short half-life of this radionuclide $\left(t_{1 / 2}=20.4 \mathrm{~min}\right)$, such syntheses pose extraordinary chemical problems with respect to the various steps involved and consequently present a challenge. ${ }^{1}$

When it comes to synthesis of ${ }^{11} \mathrm{C}$-labelled counterparts of biologically active peptides, already the preparation of the labelled L-amino acids presents very difficult problems indeed. Their subsequent partial protection and incorporation into the proper peptide represent a multistep process, generally requiring days or weeks instead of minutes, not least depending on the purification work involved. Obviously, a primary goal in this context is to reduce to its absolute minimum the number of synthetic steps involving the labelled 


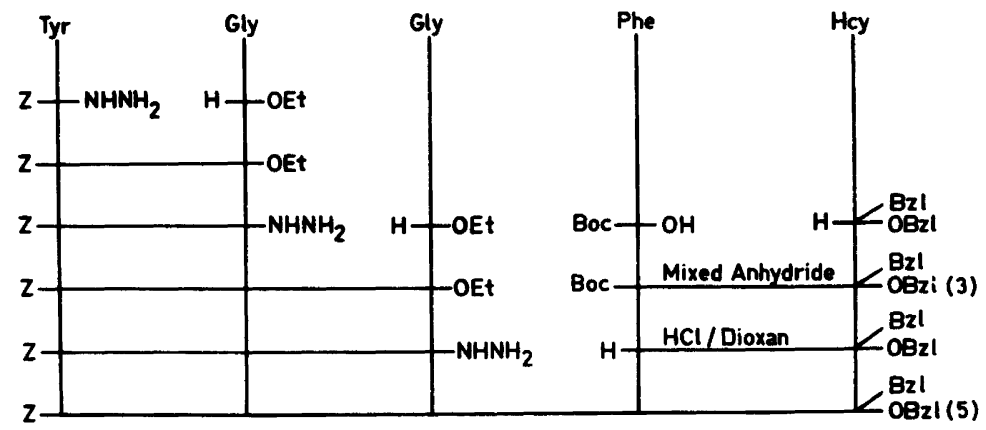

Scheme 1 .

substrate and, when possible, to devise schemes comprising the labelling at the end and only requiring simple purification afterwards.

This paper presents a scheme for the synthesis of methionine-containing peptides and demonstrates that it can be applied to the synthesis of the simple pentapeptide, methionine-enkephalin (Met-enkephalin), ${ }^{2}$ in high yield and purity. The scheme is primarily designed to comply with the requirements for future adaptation to synthesis of ${ }^{11} \mathrm{C}$-labelled peptides and is based on the application of well-established techniques in the field of peptide synthesis. Thus, $S$-benzyl homocysteine is incorporated in place of methionine (Scheme 1) in a peptide, the terminal groups of which are protected with benzyloxycarbonyl $(Z)$ and benzyl (Bzl). All chiral amino acids used in this paper are of L-configuration. The phenolic hydroxyl group of tyrosine is left unprotected during the entire synthesis. The final protected pentapeptide being crystalline, it could easily be purified. The three benzylic protecting groups can be removed in a clean reaction by sodium in liquid ammonia and directly alkylated by methyl iodide in a modest excess. Evaporating the ammonia and semipreparative HPLC lead directly to pure Met-enkephalin.

\section{RESULTS AND DISCUSSION}

The protection of thiol functions by benzyl groups has a long and successful record in peptide chemistry..$^{3-4}$ The required starting material, $S$-benzyl homocysteine, was, in this case, prepared from methionine as described for the DL-derivative. ${ }^{5}$ After transformation to the corresponding Boc-derivative, ${ }^{6}$ this could smoothly be converted to the required benzyl ester 1 by the method of Wang $e t$ al. ${ }^{7}$

All synthetic steps leading from the $S$-benzyl homocysteine benzyl ester hydrochloride 2 to the protected pentapeptide 5 were rather straightforward and relied heavily on already described precursors. The protected pentapeptide was assembled by a $(3+2)$ fragment condensation using the azide coupling method. It turned out to be crystalline and could therefore easily be purified by recrystallization. Therefore, we could concentrate our efforts on the subsequent deprotection and, especially, the final $S$-methylation step.

Reductive removal of protecting groups from peptides by sodium in liquid ammonia is known occasionally to be accompanied by the formation of by-products. ${ }^{8}$ Nevertheless, we chose this procedure (du Vigneaud methodology ${ }^{8}$ ) for our deprotection step, because of the advantage it would offer of proceeding directly with the final $S$-methylation step. Originally, 


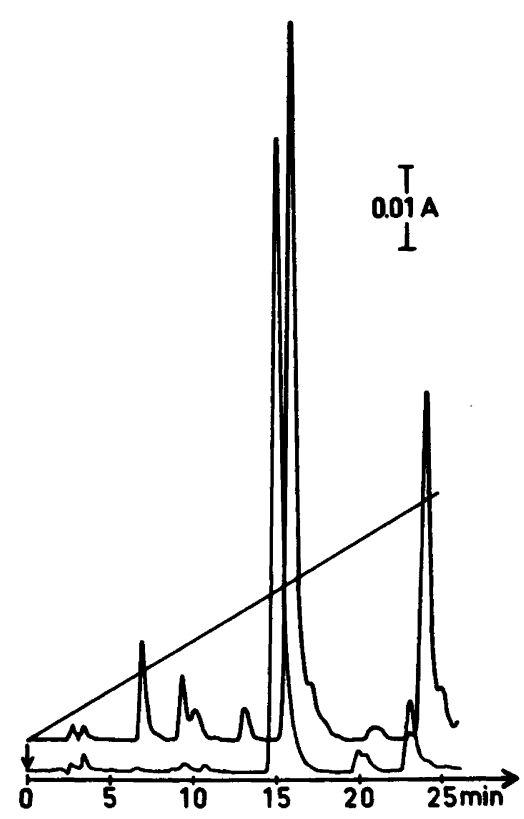

Fig. 1. Analytical separation of typical crude Met-enkephalin mixtures after alkylation with methyl iodide. Mobile phase: 0.01 $\mathrm{M} \mathrm{NH} \mathrm{NHAC}_{4} \mathrm{O} 90$ ethanol gradient, 10 to $40 \%$ in $30 \mathrm{~min}$, flow-rate $4.0 \mathrm{ml} / \mathrm{min}$. Support: $\mu$ Bondapak/ $\mathrm{C}_{18}(10 \mu \mathrm{m}), 250 \times 7.8$ $\mathrm{mm}$. Detection: UV at $280 \mathrm{~nm}$. The purification was performed on the batch represented by the lower curve.

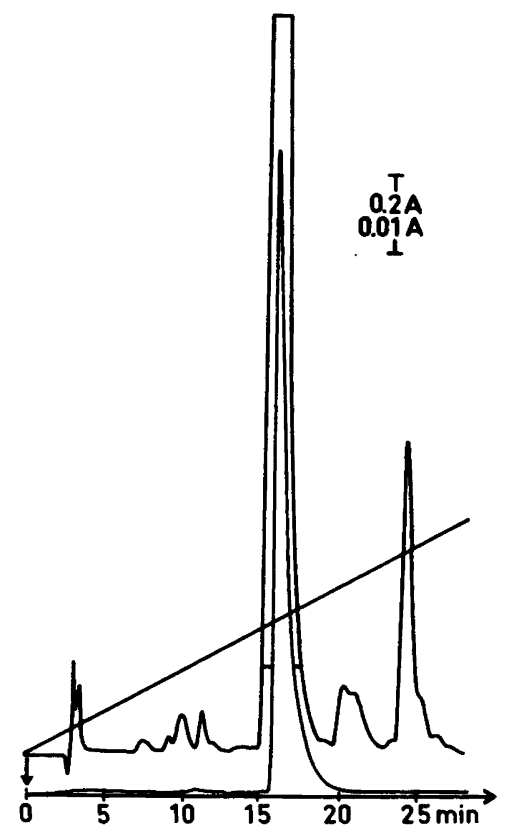

Fig. 2. Semipreparative separation of crude Met-enkephalin mixture (upper curve) and analysis of major peak (lower curve). Mobile phase, support and detection as in Fig. 1.

judging from HPLC, the results of the combined deprotection-methylation step were not always reproducible, but conditions could be found later which would give a remarkably pure crude product (Fig. 1). We believe this fact could be attributed mainly to more care being taken in handling the small amount of sodium required. Purification was finally accomplished by semipreparative HPLC on a $\mathrm{C}_{18}$ column using a volatile buffer system, from which the final product could simply be recovered by lyophilization (Fig. 2).

Although an excess of methyl iodide was employed in the final step, no evidence for overmethylation was indicated. This is in line with the results of similar experiments on small, simple model peptides. ${ }^{6,9}$ The thiol anion is obviously methylated in a highly selective fashion, even in the presence of phenolate. This is of great importance with respect to the future potential applications of our scheme to the synthesis of more complex peptides.

Experiments dealing with the preparation and use of $S$-[methyl- $\left.{ }^{11} \mathrm{C}\right]-$ Met-enkephalin are now in progress in our laboratories and the results will be reported separately. Besides for ${ }^{11} \mathrm{C}$-labelling purposes, however, the scheme reported should also be directly applicable to the synthesis of other labelled Met-enkephalins. Applying ${ }^{2} \mathrm{H}-,{ }^{3} \mathrm{H}-,{ }^{13} \mathrm{C}$ - or ${ }^{14} \mathrm{C}$-methyl iodide instead, the corresponding $S$-methyl labelled peptides should be directly obtained, which might be useful complements to those already available, commercially and otherwise, in various metabolic and other biological studies. 


\section{EXPERIMENTAL}

Melting points are uncorrected. Optical rotations were measured on a Perkin Elmer 141 polarimeter. Elemental analyses were performed at the Institute of Chemistry, University of Uppsala or Novo Microanalytical Laboratory, Bagsvaerd, Denmark, and were within $\pm 0.4 \%$ of the theoretical values. Amino acid analyses were carried out after acid hydrolysis at the Institute of Biochemistry, Biomedical Center. When not otherwise stated, organic extracts were washed twice with $1 \mathrm{M} \mathrm{NaHCO}_{3}, 1 \mathrm{M} \mathrm{KHSO}_{4}$ and brine and dried over magnesium or sodium sulfate.

Boc- Hcy $(B z l)-O B z l(1)$. A solution of $5.86 \mathrm{~g}(18 \mathrm{mmol})$ of Boc-Hcy $(\mathrm{Bzl})^{6}$ in $90 \mathrm{ml}$ of methanol and $10 \mathrm{ml}$ of water was titrated to $\mathrm{pH} 7-7.5$ with aqueous cesium carbonate and then evaporated to dryness. The residue was dissolved three times in $50 \mathrm{ml}$ of DMF with evaporation, then it was redissolved in $100 \mathrm{ml}$ of DMF and $3.25 \mathrm{~g}(19 \mathrm{mmol})$ of benzyl bromide was added during $10 \mathrm{~min}$. After stirring for $18 \mathrm{~h}$, the cesium bromide was filtered off and the solvent evaporated. The product was distributed between $200 \mathrm{ml}$ of ethyl acetate and $100 \mathrm{ml}$ of water and the organic phase was washed twice with $1 \mathrm{M} \mathrm{NaHCO}_{3}$, twice with brine, and dried $\left(\mathrm{Na}_{2} \mathrm{SO}_{4}\right)$. After evaporation, the oily residue was dissolved in DMF and precipitated with water. The solid precipitate was crystallized from petroleum ether and recrystallized from hexane, giving $3.56 \mathrm{~g}(48 \%)$ of the pure product, m.p. $57-58^{\circ} \mathrm{C},[\alpha]_{\mathrm{D}}^{25}$ $-28.0^{\circ}$ (c 1.0, MeOH). Anal. $\mathrm{C}_{23} \mathrm{H}_{29} \mathrm{NO}_{4} \mathrm{~S}: \mathrm{C}, \mathrm{H}, \mathrm{N}, \mathrm{S}$.

$\mathrm{Hcy}(\mathrm{Bzl})-\mathrm{OBzl} \cdot \mathrm{HCl}(2)$. Compound $1(3.41 \mathrm{~g}, 8.2 \mathrm{mmol})$ was dissolved in $15 \mathrm{ml}$ of dioxane. After the addition of $40 \mathrm{ml}$ of $4.1 \mathrm{M} \mathrm{HCl}$ in dioxane, the solution was stirred for $3 \mathrm{~h}$ at $20^{\circ} \mathrm{C}$ (the reaction was not completed in $1 \mathrm{~h}$, according to TLC). Evaporation of the solvent gave an oily residue, which failed to crystallize on trituration with ether and was used directly in the synthesis of 3 .

$B o c-P h e-H c y(B z l)-O B z l(3)$. Crude $2(8.2 \mathrm{mmol})$ was dissolved in $20 \mathrm{ml}$ of THF and $0.95 \mathrm{ml}$ of $N$-methylmorpholine (NMM) added followed by cooling to $-15^{\circ} \mathrm{C}$. A solution of $2.28 \mathrm{~g}(8.6 \mathrm{mmol})$ of Boc-Phe and $0.95 \mathrm{ml}$ of NMM in $40 \mathrm{ml}$ of THF was cooled to $-15^{\circ} \mathrm{C}$ and reacted first with $1.18 \mathrm{ml}$ of isobutyl chloroformate for one min and then with the amino component for $30 \mathrm{~min}$ at $-10^{\circ} \mathrm{C}$ and $2 \mathrm{~h}$ at $20^{\circ} \mathrm{C}$. The $\mathrm{NMM} \cdot \mathrm{HCl}$ was filtered off and the solvent was evaporated. The residue was dissolved in EtOAc, washed and dried in the usual manner. Evaporation gave a solid residue which was crystallized from ether/light petroleum, giving $3.52 \mathrm{~g}(76 \%)$ of pure 3, m.p. $106-107.5^{\circ} \mathrm{C},[\alpha]_{\mathrm{D}}^{25}-10.9^{\circ}(c 1.0$, EtOH). Anal. $\mathrm{C}_{32} \mathrm{H}_{38} \mathrm{~N}_{2} \mathrm{O}_{5} \mathrm{~S}: \mathrm{C}, \mathrm{H}, \mathrm{N}, \mathrm{S}$.

$\mathrm{Phe}-\mathrm{Hcy}(\mathrm{Bzl})-\mathrm{OBzl} \cdot \mathrm{HCl}(4)$. Compound $3(3.38 \mathrm{~g}, 6.0 \mathrm{mmol})$ was dissolved in $20 \mathrm{ml}$ of dioxane. After the addition of $30 \mathrm{ml}$ of $4.1 \mathrm{M} \mathrm{HCl}$ in dioxane, the solution was stirred for $4 \mathrm{~h}$ at $20^{\circ} \mathrm{C}$. Evaporation of the solvent resulted in an oil that was triturated with ether to give the solid product, $2.85 \mathrm{~g}(95 \%)$, m.p. $125-127^{\circ} \mathrm{C},[\alpha]_{\mathrm{D}}^{25}-12.5^{\circ}(c 1.0, \mathrm{MeOH})$.

Z-Tyr-Gly-Gly-Phe-Hcy(Bzl)-OBzl (5). Z-Tyr-Gly-Gly-NHNH 2 (2.30 g, 5.2 mmol), m.p. $198-200^{\circ} \mathrm{C},[\alpha]_{\mathrm{D}}^{25}-21.0^{\circ}$ (c 1.0, DMF) (reported ${ }^{7} \mathrm{mp} .198-201^{\circ} \mathrm{C},[\alpha]_{\mathrm{D}}^{25}$ $-21.86^{\circ}(c 1, \mathrm{DMF})$ ), prepared according to Scheme 1, was dissolved in $40 \mathrm{ml}$ of DMF and cooled to $-20^{\circ} \mathrm{C}$ before the addition of $6.34 \mathrm{ml}(26 \mathrm{mmol})$ of $4.1 \mathrm{M} \mathrm{HCl}$ in dioxane and 1.00 $\mathrm{ml}(7.28 \mathrm{mmol})$ of isopentyl nitrite. After stirring for $1 \mathrm{~h}$ at $-20^{\circ} \mathrm{C}$, the solution was cooled to $-30^{\circ} \mathrm{C}$ before the addition of $4.4 \mathrm{ml}(31.2 \mathrm{mmol})$ of triethylamine (TEA) and $2.73 \mathrm{~g}(5.46$ mmol) of 4. During $1 \mathrm{~h}$ the temperature was allowed to reach $+4^{\circ} \mathrm{C}$ at which temperature the reaction mixture was then finally stirred for $21 \mathrm{~h}$, while some further TEA was added to maintain the $\mathrm{pH}$ slightly basic.

After removal of the precipitated hydrochloride by filtration and the solvent by evaporation, the residue was dissolved in EtOAc, which was washed and dried in the usual manner. The solvent was withdrawn until precipitation began. Crystallization from EtOAc gave $2.45 \mathrm{~g}(54 \%)$ of the pure product, m.p. $189-191^{\circ} \mathrm{C},[\alpha]_{\mathrm{D}}^{25}-23.5^{\circ},(c 1.0, \mathrm{DMF})$. Anal. $\mathrm{C}_{48} \mathrm{H}_{51} \mathrm{~N}_{5} \mathrm{O}_{9} \mathrm{~S}: \mathrm{C}, \mathrm{H}, \mathrm{N}, \mathrm{S}$.

Tyr-Gly-Gly-Phe-Met (Met-enkephalin). Treatment of peptide derivatives with sodium in liquid ammonia must be performed under anhydrous conditions to avoid splitting peptide bonds. The following precautions were therefore taken. Sodium was melted in toluene and sucked up into a graded $2 \mathrm{ml}$ pipette. Shortly before use, the pipette was cut in a dry glove box and sealed with plastic film to preserve the fresh sodium surface. Ammonia was first dried with sodium in a separate vessel and then distilled into the reaction vessel. 
The system was protected with dry nitrogen gas during the distillation and the subsequent reactions.

Peptide $5(87.4 \mathrm{mg}, 0.10 \mathrm{mmol})$ was dissolved in $30 \mathrm{ml}$ of ammonia at $-70^{\circ} \mathrm{C}$. The sodium pipette was then connected to the system through a screw cap. The tip of the pipette was dipped gently into the solution a number of times during 3 to $5 \mathrm{~min}$ until a persistent (more than $2 \mathrm{~s}$ ) uniform blue colour was obtained. The solution was then immediately neutralized with a small amount of ammonium chloride. Methyl iodide in hexane $(0.25 \mathrm{ml}$ of $0.8 \mathrm{M}$ solution) was added and the reaction mixture stirred for $1 \mathrm{~h}$ while the temperature was increased from -70 to $-25^{\circ} \mathrm{C}$. The ammonia was boiled off at $0{ }^{\circ} \mathrm{C}$ and the residue dissolved in $4 \mathrm{ml}$ of $10 \%$ aq. acetic acid (v/v). $3.6 \mathrm{ml}$ of the solution was purified in four runs on a Waters HPLC system, equipped with a $250 \times 7.8 \mathrm{~mm}$ (i.d.) Micro-Bondapak $\mathrm{C}_{18}$ column $(10 \mu \mathrm{m})$ using a gradient system of $90 \%$ ethanol in $0.010 \mathrm{M}$ ammonium acetate, $10 \%$ to $40 \%$ in $30 \mathrm{~min}$ with a flow rate of $4 \mathrm{ml} / \mathrm{min}$. The separation was monitored at $280 \mathrm{~nm}$. The fractions containing the product were evaporated and lyophilized, giving $41.9 \mathrm{mg}$ of a product with a peptide content of $84 \%$. Amino acid analysis: Tyr 0.98 , Gly 2.04, Phe 0.98, Met 0.93 . The total yield of Met-enkephalin was $69 \%$.

Acknowledgements. This work was financed by grants from the Swedish Natural Science Research Council (K-DT 1777-100, K-KU 2446-107 and K-KU 3020-112). The generous support and advice of Prof. G. Bergson was much appreciated.

\section{REFERENCES}

1. Långström, B., Bergson, G., Dannals, R.F., Halldin, C., Någren, K., Ravert, H. and Svärd, H. In Greitz, T., Ingvar, D.H. and Widén, L., Eds., The Human Brain Studied with Positron Emission Tomography, Raven, New York. In press.

2. Hughes, J., Smith, T.W., Kosterlitz, H.W., Fothergill, L.A., Morgan, B.A. and Morris, H.W. Nature 258 (1975) 577.

3. Bodanszky, M. Principles of Peptide Synthesis, Springer, Berlin 1984, p. 133.

4. du Vigneaud, V., Audrieth, L.F. and Loring, H.S. J. Am. Chem. Soc. 52 (1930) 4500.

5. Armstrong, M.D. Biochem. Prep. 5 (1957) 91.

6. Långström, B., Sjöberg, S. and Ragnarsson, U. J. Labelled Compd. Radiopharm. 18 (1981) 479.

7. Wang, S.-S., Gisin, B.F., Winter, D.P., Makowske, R., Kulesha, I.D., Tzougraki, C. and Meienhofer, J. J. Org. Chem. 42 (1977) 1286.

8. Wünsch, E. In Houben-Weyl, Methoden der Organischen Chemie, Thieme, Stuttgart 1974, Vol. 15, Part 1, p. 234.

9. Connors, T.A., Mauger, A.B., Peutherer, M.A. and Ross, W.C.J. J. Chem. Soc. (1962) 4601.

Received May 24, 1984. 